\title{
Should general practitioners call patients by their first names?
}

\author{
Brian McKinstry
}

\begin{abstract}
Objective - To assess the acceptability to patients of the use of patients' first names by doctors and doctors' first names by patients in general practice.

Design-An administered questionnaire survey.

Setting-5 General practices in Lothian.

Patients - 475 Patients consulting 30 general practitioners.

Main outcome measure-Response by patients to questionnaire on attitude to use of first names.

Results - Most of the patients either liked (223) or did not mind (175) being called by their first names. Only 77 disliked it, most of whom were aged over 65 . Most patients (324) did not, however, want to call the doctor by his or her first name.

Conclusions-General practitioners should consider using patients' first names more often, particularly with younger patients.
\end{abstract}

\section{Introduction}

For many years the way that doctors address their patients has been a topic of discussion. As social habits have become less formal the familiar form of address has become more common, and people often refer to others by their first name rather than by their title and surname. To some extent the United Kingdom is following the lead of the United States, which has adopted this style for many years. Doctors in the United Kingdom have been less enthusiastic about adopting this approach with their patients, although their nursing colleagues are much less formal, particularly with older patients.

Some authors have thought strongly that doctors should not address patients by their first names because it is patronising and reduces the status of patients when they already feel vulnerable. ${ }^{14}$ Others think that the familiar address puts patients at ease. ${ }^{5}$ Some work done on this on a small scale in hospitals in the United States and the United Kingdom showed that patients generally preferred their first names to be used, ${ }^{56}$ but no large study has been done in general practice in the United Kingdom.

The aim of my study was to determine how acceptable the use of first names is to patients. I tried to establish whether there are any demographic "ground rules" that might help doctors decide how to address their patients. I also tried to find out whether patients would like to call their doctor by his or her first name.

Ashgrove Health Centre, Blackburn, West Lothian Brian McKinstry, MRCGP, general practitioner

Br Med f 1990;301:795-6 women as men and was slightly skewed towards the lower social classes (see table III) was typical of populations attending general practices. ${ }^{.}$The patients were asked how often they were called by their first names, how much they liked or disliked this, how often they called the doctor by his or her first name, and if they thought they should do this. The practices surveyed comprised three in Edinburgh and two in West Lothian.

I attempted to survey patients at different times of the day, and the interviewer visited each surgery on five occasions. On average just over $70 \%$ of patients attending the surgeries at these times were surveyed. Almost all the patients attending some surgeries were surveyed, though on one day in one surgery only about one fifth of those attending were surveyed because of misdirection by the reception staff. In the busier surgeries the interviewer was unable to see all the patients and if queues became too long patients were told that they could leave. Inevitably, however, some self selection must have operated, with those who were too busy to be surveyed or uninterested not waiting to be interviewed. The findings were analysed for age, sex, social class, and differences among practices. Significance was determined by the $\chi^{2}$ method.

\section{Results}

The patients were initially asked if when they visited the doctor he or she called them by their first name. As answers they were offered the choice of: yes almost always, sometimes, or never. Table I shows that 305 of the 475 patients were never called by their first name, but further analysis showed that younger patients (aged $\leqslant 30$ ) were much more likely to be called by their first names than older patients $(>65), 46 \%(50 / 109)$ compared with $10 \%(10 / 102)$; difference $(95 \%$ confidence interval) $36 \%$ (25\% to $47 \%$ ). There was no association with class or sex on this question. There was, however, some variation among practices, with one practice recording about half the proportion of positive replies of the others.

The patients were then asked if they liked to be called by their first name. They were offered the

TABLE I-Patients' responses when asked if the doctor called them by their first name according to their age

\begin{tabular}{lccrc}
\hline & \multicolumn{3}{c}{ Response } \\
\cline { 2 - 4 } $\begin{array}{l}\text { Age } \\
\text { (years) }\end{array}$ & $\begin{array}{c}\text { Yes almost } \\
\text { always }\end{array}$ & Sometimes & Never & Total \\
\hline $13-\star$ & 5 & & 2 & 7 \\
$18-$ & 45 & 17 & 40 & 102 \\
$31-$ & 30 & 25 & 104 & 159 \\
$51-$ & 16 & 12 & 77 & 105 \\
$>65$ & 10 & 10 & 82 & 102 \\
\hline Total & 106 & 64 & 305 & 475
\end{tabular}

${ }^{\star}$ Group combined with group aged 18-30 when calculating $\chi^{2}$ value because of small numbers. $\chi^{2}=56.6, d f=6, p<0.001$ patients comprised 147 male patients and 328 female patients, of whom 63 were single, 327 married, 37 separated or divorced, and 48 widowed. The fact that the surveyed population contained twice as many

\section{Patients and methods}

Overall, 475 patients consulting 30 doctors in five general practices in Lothian completed a questionnaire 
TABLE II - Patients' responses when asked if they liked to be called by their first name according to age

\begin{tabular}{lccccc}
\hline & \multicolumn{5}{c}{ Response } \\
\cline { 2 - 6 } $\begin{array}{l}\text { Age } \\
\text { (years) }\end{array}$ & $\begin{array}{c}\text { Yes almost } \\
\text { always }\end{array}$ & $\begin{array}{c}\text { Yes but only } \\
\text { if I know } \\
\text { doctor well }\end{array}$ & $\begin{array}{c}\text { I don't } \\
\text { really mind }\end{array}$ & $\begin{array}{c}\text { Not really } \\
\text { but it doesn't } \\
\text { bother me }\end{array}$ & $\begin{array}{c}\text { I really } \\
\text { don't like } \\
\text { it at all }\end{array}$ \\
\hline $13-\star$ & 6 & 1 & & & \\
$18-$ & 66 & 3 & 30 & 1 & 2 \\
$31-$ & 68 & 19 & 55 & 2 & 15 \\
$51-$ & 29 & 5 & 43 & 7 & 21 \\
$>65$ & 22 & 4 & 47 & 8 & 21 \\
\hline Total & 191 & 32 & 175 & 18 & 59
\end{tabular}

*Group combined with group aged $18-30$ when calculating $\chi^{2}$ value because of small numbers.

$\chi^{2}=79 \cdot 8, \mathrm{df}=12, \mathrm{p}<0.001$

TABLE III - Patients' responses when asked if they liked to be called by their first name according to social class

\begin{tabular}{|c|c|c|c|c|c|c|}
\hline \multirow[b]{2}{*}{$\begin{array}{l}\text { Social } \\
\text { class }\end{array}$} & \multicolumn{5}{|c|}{ Response } & \multirow[b]{2}{*}{ Total } \\
\hline & $\begin{array}{l}\text { Yes almost } \\
\text { always }\end{array}$ & $\begin{array}{c}\text { Yes but } \\
\text { only if I } \\
\text { know } \\
\text { doctor well }\end{array}$ & $\begin{array}{l}\text { I don't } \\
\text { really } \\
\text { mind }\end{array}$ & $\begin{array}{c}\text { No but it } \\
\text { doesn't } \\
\text { bother me }\end{array}$ & $\begin{array}{c}\text { I really } \\
\text { don't } \\
\text { like it } \\
\text { at all }\end{array}$ & \\
\hline I & 9 & 4 & 8 & 3 & 11 & 35 \\
\hline II & 22 & 5 & 20 & 1 & 9 & 57 \\
\hline III & 84 & 10 & 67 & 10 & 18 & 189 \\
\hline IV & 44 & 8 & 49 & 1 & 12 & 114 \\
\hline V & 32 & 5 & 31 & 3 & 9 & 80 \\
\hline Total & 191 & 32 & 175 & 18 & 59 & 475 \\
\hline
\end{tabular}

following choices of answer: yes almost always; yes but only if I know the doctor well; I don't really mind either way; no not really but it doesn't bother me; I really don't like it at all. Table II shows that only 77 patients disliked being called by their first name, and only 59 of these really objected. Younger patients (aged $\leqslant 30$ ) were more likely to prefer being called by their first name than older patients $(>65)(66 \%(72 / 109) v$ $22 \%(22 / 102) ; 44 \%(32 \%$ to $56 \%))$ and were much less likely to dislike being called by their first names $(2 \%$ $(2 / 109)$ v $21 \%(21 / 102) ; 19 \%(10 \%$ to $27 \%))$.

Table III shows that $11(31 \%)$ of the 35 patients in social class I disliked being called by their first names compared with $48(11 \%)$ from all the other social groups (difference $20 \%$ (5\% to $36 \%$ )). Analysis of the patients in social class I in the survey, however, showed them to be mainly aged over 50. This may have influenced the results.

There was no apparent difference between the sexes and no significant variation among practices. Only one of the patients who were called by their first name disliked this. When asked if the age of the doctor made a difference to whether they liked to be called by their first name only 31 patients said yes. Those who said yes preferred an older doctor to call them by their first name.

The patients were then asked if they ever called their doctor by his or her first name. Only six said that they always did and 10 that they sometimes did. The numbers of patients saying yes were too small for further analysis, but there was no obvious bias with social class or age. Finally, they were asked if they thought that they should be able to call their doctor by his or her first name. Altogether 324 said that they would not like to do this, 115 said that they would only if they knew him or her well, and 36 said that they should be able to. The demographic characteristics of each of these three groups were similar to those of the study population as a whole. When the patients were asked if the age of the doctor made a difference only 15 thought that it mattered, and they thought it easier to call a younger doctor by his or her first name.

\section{Discussion}

I found that many patients were happy to be called by their first name, though a few (16\%) disliked it. Although older people were not as happy with the informal type of address, most of them (79\%) did not resent it, and although patients in social class I were overrepresented in the group who really did not like it, less than one third thought that way. The patients who were called by their first names almost universally liked it, and many patients commented that they thought that it helped to put them at ease with the doctor. I would contend that a less anxious patient is more likely to hear and understand the doctor's advice, and the more familiar form of address may help this.

Only six patients did or wanted to call the doctor by his or her first name, although almost a quarter thought that they should do this if they knew the doctor well. This suggests an acceptance by patients of a paternal or maternal relationship with their doctor. Some authors have argued that using the patient's first name but not the doctor's maintains this unequal relationship, which can be damaging in the long term. ${ }^{4}$ They have suggested that this induced dependency inhibits patients' ability to make decisions for themselves and to take responsibility for their health. There is, however, little evidence that a paternal or maternal relationship reduces the doctor's effectiveness as a healer; this is worthy of further research.

The study was done in Edinburgh and West Lothian, and it is hard to know how relevant these results are to other parts of the country. Edinburgh is not particularly renowned for its informality, and possibly in other areas a higher proportion of patients might like to be called by their first name. General practice in the United Kingdom is entering a period of increasing consumerism and competition, and giving the patient what he or she wants in the style of practice will assume greater importance. My findings suggest that doctors should consider using first names more often, particularly with younger people.

I thank all the general practitioners who kindly let me interview their patients; Mrs E MacFarlane, who administered the questionnaire; Ms Audrey Walker, librarian at St John's Hospital, West Lothian; Professor J G Howie and Mr $M$ Porter of the department of general practice, Edinburgh University, for their help and encouragement; and Dr R Prescott of the department of medical statistics, Edinburgh University, for his statistical advice. This project was assisted by the Scientific Foundation Board of the Royal College of General Practitioners.

1 Connant E. Addressing patients by their first names. $N$ Engl f Med 1983;308:

Dudley H, Baker L. How's your form of address going matey! Orright? BrMed f 1988;297:1699.

3 Furlow TW. Clinical etiquette: a critical primer. JAMA 1988;260:2558-9.

4 Lavin M. What doctors should call their patients. F Med Ethics 1988;14:129-31 5 Elizabeth J. Form of address: an addition to history taking? Br Med $\mathcal{F}$ 1989;298:257.

6 Dunn JL, Lee TH, Percelay JM, et al. Patient and house officer attitudes on physician attire and etiquette. FAMA 1987;257:65-8.

7 Office of Population Censuses and Surveys. General household survey 1987. London: HMSO, 1987:30-1.

(Accepted 18 July 1990) 